\title{
JEW AND GENTILE IN EARLY CHRISTIANITY.
}

CHRISTIANITY (as we have seen in a previous article on a kindred subject ${ }^{1}$ ) is the natural product of a historical process. When by the conquests of Alexander the Great the barriers which separated the nations of antiquity were broken down, national prejudices began to dwindle away, and the new intercourse and mutual contact of the nations resulted in a powerful fermentation in the minds of the people, which found expression in a peculiar species of religious syncretism that gradually spread over the whole Roman Empire. This movement, consisting in the hope of religious salvation through divine enlightenment (through Bodhi, as the Hindu calls it, or, as the Greek expressed it, through Gnosis), is in all its salient features pre-Christian, and the Nazarenes of Palestine (as well as the Essenes, the Ebionites, and the Zabbæans) are but characteristic expressions of the times, having their analogies in the therapeutæ of Egypt and the pre-Christian Gnostics of Syria.

The seeds of Gnosticism that were scattered among the $\mathrm{He}$ brew people, both in Palestine and in Babylon, fell upon good ground, as preparations had been made for their reception through great sufferings. Moreover, the Jews of the disaspora were naturally predisposed to be transmitters of new religious thoughts. They knew foreign languages and acted among the Gentiles as agents in business and commerce. In the history of religion, too, they play the important part of brokers, furnishing the nations with a stock exchange of philosophical thought.

For these reasons it is natural that Syria, Alexandria, and the

1 "Gnosticism in its Relation to Christianity," The Monist, Vol. VIII., p. 502. 
cities of Asia Minor, all of which were great centers of the Jewish disaspora, should become the seats of Gnostic teachings and of an anxious search for new truths.

The Jews came into the closest and most friendly contact with the Persians, one of the most ideal nations of antiquity, whose religious faith was free from idolatry of every kind and philosophically purer than any other religion. Ahura Mazda, the Lord Omniscient, was not worshipped after the manner of pagan adoration, for the Persians conceived him to be spirit without body. His appearance, if comparable to anything, was deemed to be most like the light, and his soul was defined as the truth. Life was regarded as a struggle between good and bad, in which we must take part. Zarathustra taught that a great crisis was at nand. The bad is powerful now, but in the end the good will conquer. Saviours arise from time to time, and at last the saviour (saoshyaut) will appear, the son of a virgin, and his name shall be Righteousness Incarnate. Then the great day of judgment will come which shall purge the world of all evil through the ordeal of molten metal. The new order of things will include those who have passed away; the dead shall be raised, but the future body (tanit-i-pasin) will be so ethereal as to cast no shadow.

Even in the canonical literature of the Israelites, the Lord Omniscient (Ahura Mazda) of the Persians is identified with Jahveh; and Cyrus, the liberator from the Babylonian yoke, is greeted as the Messiah. ${ }^{1}$

How could the religion of the Jews remain uninfluenced by the Persian doctrines? If Babylonian beliefs and institutions, which constituted the religion of a hated oppressor, proved strong enough to modify the old traditions of Jahvehism and introduced new legends, ${ }^{2}$ festivals, ${ }^{8}$ and customs, ${ }^{4}$ how natural it is that the purer

1 Isaiah c. 43.

${ }^{2}$ The story of the creation in six days, the legends of the flood, of the destruction of impious cities by a rain of fire, the finding of Moses, etc.

${ }^{3}$ The Purim festival is a Judaised version of the celebration of Bel's victory over Tiamat. Marduk is Mordachai, Isthara is Esther.

1 The institution of the Sabbath is of most ancient origin in Mesopotamia. 
and more elevating Zarathustrian faith of the Persian liberators should have left its imprint upon the grateful minds of the Jews! We know, for instance, from the Septuagint that the Persian king Cyrus regulated the worship of the Lord (Ahur, or kv́plos) in the temple of Jerusalem ${ }^{1}$ according to Persian fashion, with an eternal light.

Mazdaism, the Persian religion, is a strict monotheism, which, however, personifies the qualities of God, and thus gave rise, on the one hand, to the doctrine of angels and archangels, and, on the other, to the conception of a plurality of the energies or activities of God, which were spoken of as Spenta Mainyu, the Holy Spirit (similar in conception to the Christian Holy Ghost), as the Good Thought (Vohu Manha), as the Divine Wisdom (Khratu), as the Kingdom or the Good Kingdom (for the coming of which prayers were said), as the Pure and Stirring Word that existed before anything else and through which the world was made. ${ }^{2}$

By the side of Mazdaism, we find Indian influences that made themselves felt among the Jews. The authors of Alexandrian Judaism (among whom Philo is the most renowned and the most learned) make frequent mention of the Gymnosophists, the Jains of India, and expound some of their strange doctrines. Buddhism itself, so similar in many respects to Christianity, is nowhere specially mentioned in the contemporaneous literature of this age, and yet we have indubitable though meagre vestiges of Buddhist

The word sabbatu is Accadian and means "day of rest." The Babylonians adopted it from the Accadians and transmitted it to the Assyrians.

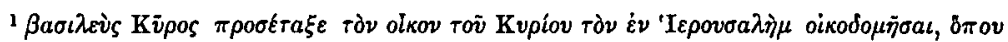

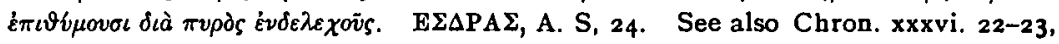
repeated in Esra i. I-2.

${ }^{2}$ For brief but instructive accounts of all these striking doctrines of Mazdaism, see Prof. A. V. Williams Jackson's articles, one in The Monist, Vol. IX., No. 2, p. 161, the other in The Biblical World, Vol. VIII., No. 2. We have urged our learned contributor to compile a book on the religion of the Persians and to set into strong relief the prophetic anticipations of Christianity to be found in the Zarathustrian faith. It is a book greatly needed. It would throw much light on the origin of Christianity and at the same time explain why dominion over all Asia was given to the Persians, to the nation that had the purest religion; and we should also see how they were enabled to rule the world until their fidelity to the pure morality of their religion began to relax. 
traditions in the New Testament itself, making it certain that its doctrines were not quite unknown in Syria in the days of Christ. There are several curious parallelisms between the accounts of Buddha's life and the Christian Gospels, too similar in details and too frequent to be purely accidental; the Buddhist Jataka tales migrated West in the shape of Esop's fables and in the story of Josaphat and Barlaam; and the Rock Inscriptions of Asoka speak of the missionaries sent to the Western Kingdoms, among which Syria and Egypt are specially mentioned. The use of the typically Bud-

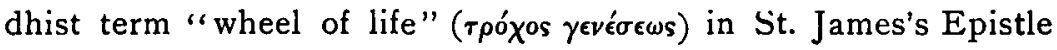
(wrongly translated in all modern versions), which was no longer understood in its original significance, is in itself irrefutable evidence of incidental Buddhist notions in Western countries. ${ }^{1}$

The canonical books of the Old Testament contain no indication of a belief in immortality, and philosophical conceptions as to the beginning and the end of the world were foreign to the $\mathrm{He}$ brew prophets and priests. The doctrine of the creation of the world was introduced into Hebrew literature in two versions, both ultimately derived from Babylonian sources. But the doctrine of an end of this world and a beginning of a new one appears only in the later apocryphal books and assumes the shape of apocalyptic visions, of revelations of the things to come.

There is only one book of this character, the revelation of St. John the Divine, left in the Christian canon, but apocalyptic literature was so powerful a factor in the building up of Christianity that we cannot pass the subject by without a few comments.

The prototype of all revelations of Judaism, Gnosticism, and Christianity, including the Divina Comedia of Dante, seems to be the Artā Virāf Namak, a vision of Heaven and Hell as seen by the Zoroastrian prophet Arta Viraf. In Hebrew literature the eschatological spirit, which first appears in Ezekiel and Daniel, made a deep impression on the religious mind of the Jews, and soon a veritable flood of revelations appeared, among which the book of Henoch is the most noteworthy product of the fermenting process

'See the author's Buddhism and its Christian Critics, pp. 165-194. 
of the age. Other books of more or less importance are the As. sumption of Moses, the Revelation of Moses, the Revelation of Baruch, the Sibyllines, the little Genesis (also called the book of the Jubilees), the prophecy of Esdras and others. ${ }^{1}$

The character of the Revelation of St. John the Divine remained an unsolved problem to the investigators of New Testament history, until its connexion with the apocalyptic books of the Old Testament was understood. St. John's apocalypse was received within the canon of the New Testament not without serious protests, and yet it is one of the most genuine Christian writings, representing a very important phase in the development of the Church, and mirroring the period of transition from Judaic Christianity to the establishment of the Gentile Church. Besides the apocryphal books of the Old Testament, which show traces of the older Gnosticism and constitute a transition to the literature of the New Testament, there is the formation of those Jewish sects enumerated above which profess a belief in the coming of the Good Kingdom which is thought to be near at hand with its new order of things.

There can be no doubt about the pre-Christian existence of the Nazarenes, for Christ himself is called a Nazarene; and the name of this sect remained for several centuries the name of the Jewish Christians. St. Paul, soon after his conversion to Christianity, is spoken of by the Jews, according to the report in the Acts, as a ringleader of the Nazarenes. It is difficult to decide whether the

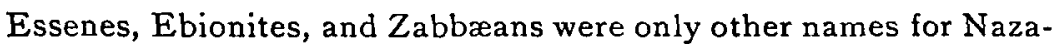
renes, or whether they were different congregations of a kindred

1 See Hilgenfeld, Die jildische Apokalypse. As to the prophecy of Esdras we have to add that it is one of the most superior productions of apocalyptic writings. It contains several passages of vigor and poetic beauty, while the crudities which are an almost indispensable accompaniment of this class of literature are less offensive than in the Revelation of St. John the Divine. We no longer possess the original of Esdras, the date of which has not as yet been determined, but only versions in Latin, Ethiopic, Syriac, Arabic, and Armenian. Parts of the book show evidences of emendations of the first century of our era; a fact, however, which does not exclude the possibility of the bulk of the work's being pre-Christian. Certainly, neither Christians nor Jews of the first century could very well have spoken of Christ, of the Messiah or Anointed One, as does the author of the prophecy of Esdras. The vision of the eagle may be a later addition. 
spirit. If different, they were certainly children of the same Gnostic movement, and all of them cling to the common ideal of trying to realise the kingdom of Heaven on earth. There was probably a vast difference of opinion as to the nature of the kingdom of God and the method of its realisation, but this much was the accepted belief of all, that a saviour, a leader like Joshua, would come and introduce the new order of things.

Our reports of the early Jewish Christianity are very meager. They are practically limited to passages in the Epistles of St. Paul, to the Acts of the apostles, and a few passages in the literature of the Church Fathers; but they are sufficient to prove that the oldest Christian congregation was a communistic society which held all things in common. We read in the Acts (ii. 42-47):

" And they continued steadfastly in the apostles' doctrine and fellowship, and in breaking of bread, and in prayers.

" And fear came upon every soul: and many wonders and signs were done by the apostles.

"And all that believed were together, and had all things common;

"And sold their possessions and goods, and parted them to all men, as every man had need.

"And they, continuing daily with one accord in the temple, and breaking bread from bouse to house, did eat their meat with gladness and singleness of heart.

"Praising God, and having favour with all the people. And the Lord added to the church daily such as should be saved."

And again (iv. 34-37):

"Neither was there any among them that lacked: for as many as were possessors of lands or houses sold them, and brought the prices of the things that were sold,

"And laid them down at the apostles' feet: and distribution was made unto every man according as he had need.

"And Joses, who by the apostles fas surnamed Barnabas, (which is, being interpreted, The son of consolation, ) a Levite, and of the country of Cyprus,

"Having land, sold it, and brought the money, and laid it at the apostles' feet."

In the enthusiasm of the Pentecost awakening many well-to-do citizens had joined the congregation and thus "there was in those days not any one among them that lacked." But the times changed, 
for we know from the fact that collections were made among the Gentile Christians for the Saints at Jerusalem that the communistic experiment of early Christianity proved a failure and was not repeated by St. Paul. It is noteworthy that Peter in his Pentecost sermon says, not that Jesus was Christ, but that being raised from the dead and having ascended to Heaven, "God hath made that same Jesus whom ye have crucified both Lord and Christ." The main trend of Peter's Pentecost sermon is eschatological. He quotes as words of God sentences from Joel and Zachariah, giving them an apocalyptic interpretation, in referring them to the day of judgment, saying (Acts ii. 19-20):

"And I will shew wonders in heaven above, and signs in the earth beneath; blood, and fire, and vapour of smoke :

"The sun shall be turned into darkness, and the moon into blood, before that great and notable day of the Lord come."

Otherwise Peter preaches the doctrine of St. John, the Zabbæan, only adding thereto the name of Jesus and promising the gift of the Holy Ghost, saying :

"Repent ye and be baptised, every one of you, in the name of Jesus Christ, for the remission of sins, and ye shall receive the Holy Ghost."

The Gentile Christianity was founded by St. Paul, not as a continuation of the Nazarene doctrines, but in perfect independence of the early Church at Jerusalem.

Paul prides himself on the fact that he owes nothing to the other apostles, saying, "I neither received the gospel of man, nor was I taught it, but by the revelation of Jesus Christ." $\mathrm{He}$ interprets his downfall on the road to Damascus and the flash he saw when struck with blindness for several days, as a Christophany, and claims therefore to have seen Christ face to face. Apparently he cares very little about the historical facts of the life of Jesus, for he purposely avoids contact with the disciples of Jesus, saying (Gal. i. I7):

"Neither went I up to Jerusalem to them which were apostles before me; but I went into Arabia and returned again unto Damascus."

Paul's first meeting with Peter and James apparently did not 
serve the purpose of instruction, but was merely a visit for the establishment of friendship and good-will. Paul says (Gal. i. I 8-20):

" Then after three years I went up to Jerusalem to see Peter, and abode with him fifteen days.

"But other of the apostles saw I none, save James the Lord's brother.

"Now the things which I write unto you, behold, before God, I lie not."

Paul is very explicit in relating all his connexions with the Jewish Christians. He continues:

"Afterwards I came into the regions of Syria and Cilicia ;

"And was unknown by face unto the churches of Judæa which were in Christ.

"But they had heard only, that he which persecuted us in times past now preacheth the faith which once he destroyed."

Then, after fourteen years of successful work among the Gentiles, having acquired a strong fellowship among them, Paul went up to Jerusalem to be recognised by his fellow-apostles, or, as he expressed it, "lest by any means I should run, or had run in vain."

The alliance which was thus formed between the Gentile Church and the Jewish Christians was possible only so long as they kept at a distance. The latter kept the law punctiliously, thinking that not one jot nor tittle should pass from it, and lived up to Christ's demand, "Sell all thou hast and give it to the poor"; the former adopted Paul's view of living in the world without being of the world. St. Paul describes their covenant in these words (Gal. ii. $9-(2)$ :

"When James, Cephas, and John, who seemed to be pillars, perceived the grace that was given unto me, they gave to me and Barnabas the right hands of fellowship; that we should go unto the heathen, and they unto the circumcision.

"Only they would that we should remember the poor; the same which I also was forward to do."

Paul was perfectly conscious of the fact that his Gospel differed from the Nazarene Christianity, for he states directly that he "communicated unto them [i. e., Peter and other pillars of the Church at Jerusalem] that Gospel which he preached among the Gentiles, but privately to them which were of reputation" (c. 2, 2).

St. Paul was perfectly satisfied that the Jewish Christians should remain Jews and retain all their particular traditions. Peter and 
the other apostles, on the other hand, cared little for the Gentile world, except that they rejoiced at the glad news of the great success of one who preached in the name of their revered Master and Lord, Jesus. A compact of mutual recognition was thus easily effected, the more so as the congregation of Jerusalem was under no obligation whatever and received considerable alms from their unknown brethren of the Gentile churches. The report in the Acts of the apostles stands in many respects in flat contradiction to the version given by St. Paul, but we need not hesitate to regard St. Paul's statements as direct evidence of historical facts, while the Acts of the apostles is a later compilation. It contains genuine sources of unquestionable value (the so-called we-passages), but is also filled with doubtful legends, and the redactor did his work with a definite and obvious purpose, which is apologetic in its tendency and attempts to prove that the authority of the Gentile Church has been derived from Jesus through the twelve apostles, a fact which becomes more than doubtful when considered in the light of St. Paul's own words.

We need not enter here into the conflict to which St. Paul alludes, but we can understand St. Peter's attitude when he became aware of the practical differences between the two Christianities. The conflict was unavoidable wherever Gentile and Jewish Christians came in closer contact. It never became a serious question, because after the destruction of Jerusalem the Nazarenes lived in inaccessible villages of Syria, and the Jewish Christians of the disaspora were like Paul partly under Gentile influence themselves and partly too weak to convert the rest of the world to their Judaism.

In all particulars the Nazarenes remained Jews and gave little heed to the Gentile world; but with the powerful development of the Gentile Church they came to be regarded as a sect of heretics. Epiphanius ${ }^{1}$ tells us that after their flight from Jerusalem $70 \mathrm{~A} . \mathrm{D}$. they lived in Decapolis (Pella) and Basanitis (Cacabe), CoeleSyria. Being poor and living in obscure and almost inaccessible

\footnotetext{
${ }^{1}$ Pan, xxix. 7.
} 
parts of Syria, they were little heeded and are rarely mentioned in patristic literature. For all we know there may have been, at least prior to the destruction of Jerusalem, Nazarenes who did not believe in Jesus as the Messiah, and it is certain that they were otherwise Jews. We read in the Acts that there were disciples of John left, but it seems that they were soon absorbed by the Jewish Christians; still some may have kept to themselves, and Origen ${ }^{1}$ actually states that the Ebionites are divided into two sects, one of which denies the virgin birth of Jesus. Eusebius ${ }^{2}$ also discriminates between those who do and others who do not acknowledge the supernatural origin of Christ; and lastly Jerome ${ }^{8}$ says that "anxious to be both, Jews and Christians, they are neither the one nor the other." They had a gospel of their own, called "the Gospel of the Hebrews," 4 which is sometimes quoted by Church Fathers in refutation of their heresies and was lost when the Nazarenes disappeared. The problem whether Jewish Christians or Gentiles were the true followers of Jesus was finally disposed of through the disappearance of the Nazarenes.

EDItor.

$$
{ }^{1} \text { Contra Celsum, V., 6r. } \quad{ }^{2} \text { H. E., III., } 27 . \quad{ }^{3} \text { Ep. } 79 .
$$

4 The theory that the Gospel of the Hebrews is older than the carionical Gospels and one of their sources, is now abandoned for good reasons. It is presumably a late production written with the tendency of justifying the Jewish Christians, i. e., the successors of the Nazarenes, against Gentile Christianity. 